\section{ECONOMICS}

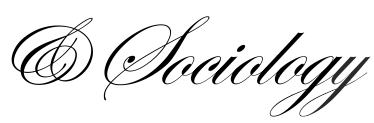

Oláh, J., Hidayat Y.A., Popp, J., Lakner, Z., \& Kovács, S. (2021). Integrative trust and innovation on financial performance in disruptive era. Economics and Sociology, 14(2), 111-136. doi:10.14254/2071-789X.2021/14-2/6

\title{
INTEGRATIVE TRUST AND INNOVATION ON FINANCIAL PERFORMANCE IN DISRUPTIVE ERA
}

\begin{abstract}
Judit Oláh
Faculty of Economics and Business, University of Debrecen, Hungary; College of Business and Economics, University of Johannesburg, Johannesburg 2006, South Africa E-mail: olah.judit@econ.unideb.bu ORCID 0000-0003-2247-1711
\end{abstract}

Yusmar Ardhi Hidayat Ibrig Károly Doctoral School, University of Debrecen, Debrecen, Hungary; Business Administration Department, Politeknik Negeri Semarang, Semarang, Indonesia, E-mail: yusmar.bidayat@econ.unideb.bu; yusmardhi@polines.ac.id ORCID 0000-0002-1835-6879

József Popp *

Institute of Economic Sciences, Hungarian University of Agriculture and Life Sciences, Gödölló, Hungary; South Africa College of Business and Economics, University of Johannesburg, Jobannesburg 2006, South Africa E-mail:popp.jozsef@uni-mate.bu ORCID 0000-0003-0848-4591

*Corresponding author

\section{Zoltán Lakner}

Szent István University, Faculty of Economics and Social Sciences, Gödöllo", Hungary

E-mail: lakner.zoltan@,szie.bu ORCID 0000-0002-2662-2241
ABSTRACT. This study aims to contribute to understanding how integrated trust and innovation affect financial performance. Our objectives can therefore be stated as follows. The first is to examine the influence of institutional trust on interpersonal trust and interorganizational trust. Subsequently, the study investigates the effect of interpersonal trust on enhancing interorganizational trust. The third purpose is to study the influence of inter-organizational trust on financial performance through innovation as a mediating variable. The study sample consists of 103 ICT companies in Hungary. The Partial Least Square (PLS) - Structural Equation Model verified the hypotheses in the research model. The results show that there appears to be a positive association between institutional trust and interpersonal trust. Institutional trust has a positive influence on inter-organizational trust, thus interpersonal trust positively affects inter-organizational trust. This study also claims that the effects of inter-organizational trust and innovation are particularly prominent and noticeable, with significant consequences for financial performance. Here we present the tests that show that interpersonal trust performed a complementary role, but innovation failed as a mediating variable. The primary suggestion we make concerns strategies to manage interpersonal trust and create a favorable sense of confidence within a company. The company should also assertively maintain trust in customers and suppliers.

\section{Sándor Kovács \\ University of Debrecen,}


Faculty of Economics and Business,

Debrecen, Hungary

E-mail:

kovacs.sandor@econ.unideb.hu

ORCID: 0000-0002-1216-346X

Received: August, 2020

1st Revision: March, 2021

Accepted: May, 2021

DOI: $10.14254 / 2071-$

789X.2021/14-2/6

JEL Classification: D23, L25, L86

Keywords: institutional trust, interpersonal trust, interorganizational trust, innovation, financial performance, PLS-SEM, ICT company, Hungary.

\section{Introduction}

With the development of Industry 4.0 in recent years, the Hungarian Information and Communication (IC) sector has had a significant impact on the economy. This sector contributed 5\% of the overall gross domestic product (GDP) back in 2018 (KSH, 2020). The IC sector is also the backbone supporting Industry 4.0 in the manufacturing sector, which contributes $22 \%$ of GDP. Besides, the innovative applications of the IC sector also enable other sectors, such as wholesale and retail trade, public administration, real estate and transportation to perform e-business. The IC sector in Hungary consists of about 1400 ICT companies. They booked revenues of approximately 0.7 billion euros in 2018, and this was expected to surge by approximately $45 \%$ in 2019 (EMIS, 2020). This upward trend is expected to continue, to be followed by the challenges to achieve and maintain significant returns under conditions of competitive pressure (Oláh et al., 2019a). As a result of these pressures, about $10 \%$ of ICT companies have closed down in the last two years (EMIS, 2020).

In order to survive in a disruptive era, ICT companies should maintain efficient production, develop trusted collaborations, and improve innovation to achieve profit. These issues have been thoroughly studied and well documented by various scholars, particularly Bilan et al. (2019) and Lechman (2018). In an internal organization, trust supports both efficiency (Sako, 1992) and effectiveness by simplifying interpersonal relations and internal integration (Bugdol, 2013). The ability to enhance interpersonal trust within a company has been confirmed by better productivity in employees' performance. In turn, workers' productivity may improve a company's performance (Brower et al., 2009; Fulmer \& Gelfand, 2012). Studies have validated a consistent connection between interpersonal trust and a company's performance (Brower et al., 2009; Fulmer \& Gelfand, 2012; Kliestikova et al., 2017). Indeed, some analyses have shown that interpersonal trust may reduce internal transaction costs (Davis et al., 2000; Dyer \& Chu, 2003; Zvaríková \& Majerová, 2014).

Observational studies have made evident the fact that ICT companies should create a network with their business partners to support production (Ključnikov ${ }^{1}$, et al., 2019; Oláh et al., 2017) and maintain social collaboration (Mura et al., 2015; Oláh et al., 2019b), and to access pivotal resources (Pratono, 2018). More recently, it has been revealed that a social network including trust in partners enhances business performance as a result of reducing external transaction costs (Almășan et al., 2019; Sako, 1992; Sako \& Helper, 1998). This finding was 
also backed by Uzzi (1996). Williamson (1993b) concluded that trust as an economic safeguard in networking may reduce transaction costs and increase innovation (Meyer \& Meyer, 2017; Molina-Morales et al., 2011; Vaníčková \& Szczepańska-Woszczyna, 2020). Some studies have also observed a strong relationship between inter-organizational trust, business performance, and innovation (Kovacova et al., 2019; Wang et al., 2011; Zaheer et al., 1998). In fact, innovation implies greater trust within collaborations due to extensive time problems, the appropriation of further risk, and a greater reliance on external forces (Afonasova et al., 2019; Revilla \& Knoppen, 2015; Todorović et al., 2019). This is consistent with the idea that external authorities, such as institutions, may provide legal protection and an appropriate business climate as the requirements for collaborations (Goergen et al., 2013). As a consequence, performance of various institutions may promote trust in the institutions which they are connected to, to rebuild - or to weaken - interpersonal trust and trust in business partners (Brehm \& Rahn, 1997; Levi, 1996; Sroka et al., 2014).

Recent studies have shown that trust is a decisive concept related to firm performance, but this remains an arguable area of inquiry. Although the majority of studies suggested that a higher level of inter-organizational trust (Robert Galford \& Anne Seibold Drapeau, 2003) had a definite impact on business performance (Allen et al., 2018; Davis et al., 2000; Dyer \& Chu, 2003; Iancu \& Nedelea, 2018), this issue remained open for debate. Recent investigations have demonstrated that trust also had an inconsistent effect on a company's performance (Baranyai et al., 2012; Robert W Palmatier et al., 2006). Besides, Johnston et al. (2004) concluded that the level of trust in business partners had no significant impact on company performance. Dvorsky et al. (2020) argued that strategic management of companies had a positive impact on their performance. Zaheer et al. (1998, p. 154) argued that interpersonal trust within a company had no direct effect on performance. Regarding the impact of institutional and company performance, Goergen et al. (2013), for example, examined the idea that country trust and firmlevel trust acting together had a positive effect on performance and were substitutes for each other. Almási \& Zéman (2019) pointed out that human factors and elements of corporate controlling had a positive effect on business operations and growth. On the other hand, trust in the public and stakeholders has a negative influence on a company's profitability (Oláh et al., $2019 b$ ). From this review of different results, the main point to conclude is that limited attention in the previous research has been paid to the relationships between interpersonal trust, interorganizational trust, institutional trust and business performance simultaneously.

Therefore, in this study, we propose a novel approach to understanding how integrative trust affects financial performance. Integrative trust consists of institutional trust, internal trust, and inter-organizational trust. The conceptual framework starts from institutional trust as an external variable, which will empower both internal trust and inter-organizational trust in a company. Then, internal trust will boost the influence of trust between the company, and its partner(s), which affects innovation and financial performance. This study has three important purposes. The first objective is to investigate the influence of institutional trust on interpersonal trust and inter-organizational trust. The second objective is to evaluate the effect of interpersonal trust on empowering inter-organizational trust. The final purpose of this research is to examine the influence of inter-organizational trust on financial performance through innovation as a mediating variable. This study starts with the fundamentals of social capital, transaction cost, types of trust, innovation and financial performance, to develop a theoretical framework. We then provide details on the experimental method used, i.e. the sampling method and the operational variables. We proceed with discussing the results, and drawing the conclusions. 


\section{Literature review}

We briefly reviewed the relevant perspectives and previous studies in order to address integrative trust, innovation, and financial performance. Some of the material presented in this literature review has been published in academic journals. First, we explored the underlying theory, from the social capital connected to transaction cost and various types of trust. Then we paid special attention to discussing the direction between institutional trust, interpersonal trust and inter-organizational trust. Finally, we also reviewed the influence of inter-organizational trust on financial performance with innovation as a mediating variable to support our hypotheses.

\section{Social capital}

From our systematic review, we approached social capital theory from two perspectives, an ego-centric and a socio-centric view. The ego-centric viewpoint describes an employee or manager as a principal factor who gives and takes resources from the company's organization (Adler \& Kwon, 2002). Meanwhile, the socio-centric perspective defines how a company in a network or linkage may provide cohesiveness with business partners and enhance production capacity for mutual performance (Suseno \& Ratten, 2007). This approach is in line with other proven links between social factors and performance, such as corporate social responsibility and financial performance (Myšková \& Hájek, 2019), the effectiveness of social dialogue and outcomes for employees and entrepreneurs (S. Bilan et al., 2020), social capital, motivation and successful business continuity (Wiroto \& Taan, 2019). The socio-centric concept illustrates trust enhances a cooperative engagement between the company and its business partners. The concept of social capital, consisting of trust, social norms, networks, and mutuality may enhance mutual advantages. The internalization of social capital in a collaboration provides the opportunity to obtain an approach to assessing worthwhile sources of assets (Pratono, 2018). In this research, we describe trust and networks as the proxy of the social capital concept. Most studies have demonstrated that companies with the capability to develop trust and networks may enhance their business performance (Ayu et al., 2020; Cooke \& Wills, 1999; Cygler \& Sroka, 2017; Gaur et al., 2011; Moeller, 2009; Pratono, 2018; Seppänen et al., 2007; Shahmehr et al., 2015), which is consistent with our framework. The underlying mechanism of how trust as social capital enhances business performance is clearly framed within the transaction cost perspective.

\section{Transaction costs}

Companies generate profit and exchange costs when it produces products and services, and many firms enhances production by considering internal and external exchange costs. A company has high expenditure on the costs of its internal and external exchanges, which are referred to as transaction costs (TC). In its internal organization, companies are able to expand production by considering the capability of its internal human resources often through specialized investment in the development of human capital. As a result, employees learn and develop particular competencies to support targeted company production.

Managers control and monitor his/her employees as they perform the work. However, a manager successfully develops increased interpersonal trust in an internal company in order to reduce controlling and monitoring costs (Davis et al., 2000; Dyer \& Chu, 2003). As a result, interpersonal trust enhances work performance (Bugdol, 2013; Fukuyama, 1995; Sako, 1992). Besides, a company decides to expand its production when its internal exchange costs are 
cheaper than its external exchange costs. However, when the internal exchange costs exceed its external exchange costs; as a consequence, the company decides to expand production by implementing collaboration with its business partners. Hence, a company considers the external TC, for instance, the cost of searching for suppliers, negotiating prices, and making contracts. In addition, a company should control its partners to ensure they fulfill the agreement (Baye \& Prince, 2017; Chao, 2011).

The activities mentioned above increase the level of transaction costs. Subsequently, the company can reduce transaction costs by efficiently reducing external exchange costs within a vertical integration and/or by market governance. The firm can implement various types of vertical integration through asset specificity, when encountering uncertainty, and repeat transactions frequently (Crook et al., 2013). The company collaborates with its business partners by implementing a relationship-specific exchange. This type of exchange occurs when the parties have made a specialized investment, for example, regarding site-specificity, physical-asset specificity, dedicated assets, and human capital. Dedicated assets represent the general investment made by the company in an exchange with a particular partner. This describes the way in which a company may collaborate with its partners in order to exchange assets to support production. The collaboration is framed as a contract with the partner. The company trusts the partners to minimize the level of transaction costs. Besides, trust in partners has a governance role as it controls the partner who performs the agreements in the contract (Baye \& Prince, 2017; Crook et al., 2013; Williamson 1988). The company should manage cooperation with the partner - in collaboration with the partner - because this supports the production process (Chao, 2011). A company can reduce a partner's opportunistic behavior by implementing trust (Zaheer \& Venkatraman, 1995). The company should implement trust as a cost-effective safeguard to maintain mutual dependency with its partner's trust (Williamson, 1993a). Guarantee schemes can avoid the risks which may result in additional costs and are counter-productive to the agreements in the contract (Mugarura, 2016). If the company trusts its partner, it may benefit from minimized costs. Many scholars argue that trust involves costs when the partners do not perform the agreement. As a consequence, the company can mitigate the risk through trust in its partners. An adequate safeguard to reduce transaction costs is trust in partners and internal trust (Williamson, 1993a). Besides, institutional trust supports the level of both types of trust.

\section{Institutional trust, internal trust and inter-organizational trust}

Zaheer et al. (1998) describe trust as the expectation that a party which is relied on will fulfill its responsibilities, act in an expected way, and avoid opportunism; they also discuss the possibility of risk. Trust can be expressed in different forms, including cognitive, behavioral, and emotional, at both interpersonal and inter-organizational levels. Interpersonal trust also consists of three components: reliability, predictability, and fairness, but with an individual as both the referent and the origin of trust. Meanwhile, inter-organizational trust has three characteristics: reliability, predictability, and fairness. Institutional trust refers to the confidence level of the company in various institutions (Askvik \& Jamil, 2013; Bursian et al., 2015; Oláh et al., 2019b). Trust in the institutions in a nation will affect business. For instance, trust in government is the expected extent of a company's trust in the quality of a bureaucracy which operates autonomously from political pressure. The business believes that the government has the strength and expertise to govern without the business having to deal with severe changes in policy, and that it provides a service to business (Goergen et al., 2013; Porta et al., 1996; Rim \& Dong, 2018). 
A company starts a collaboration with a level of trust, either high or low, regarding the performance of various institutions, and for various recognized reasons (Kadefors, 2004). When managers decided to sign a contract, they call for some safeguards that ensure the transactions will be fulfilled. The government performance creates personal trust (Brehm \& Rahn, 1997; Levi, 1996). The judicial authorities also support partnerships between parties. When conflicts emerge between the parties, the law provides an ultimate safeguard to enforce the agreements in the contract (Ring \& Van de Ven, 1992). Governments, legal systems, institutions, and common rules affect cooperation (Kadefors, 2004). To sum up, the performance of various institutions creates trust and collaboration. Subsequently, institutional trust empowers internal trust and inter-organizational trust

This study notes that institutional trust, as the external variable which is part of the business climate, supports internal and inter-organizational trust. Some scholars, such as Goergen et al. (2013) and Rim and Dong (2018), argue that the level of institutional trust influences the business conditions in the internal company and the business climate in general (Brehm \& Rahn, 1997; Lim et al., 2016; Putnam, 1995).

However, research into the influence of trust in empowering these internal conditions and business networks has produced debatable results. Goergen et al. (2013) argued that high levels of firm trust combined with high levels of government trust were likely to be counterproductive and ultimately to harm firm performance (Draskovic et al., 2017; Kliestik et al., 2018). Indeed, being one of the social capital constituents (Kaasa, 2019), trust in the public and stakeholders diminished profitability (Oláh et al., 2019b). The extent of institutional trust may not improve firm performance when it is still low, but when the institutional level is high, it gives advantages to the company (Goergen et al., 2013). Since the company has trust in various institutions, the company then only needs to focus on managing internal trust and interrelational trust to enhance business performance. In proposing a novelty as the theoretical framework of this research, this study will argue that institutional trust empowers the direction of trust in partners and internal trust simultaneously. The empowered internal trust will increase the trust in partners and consequently will enhance financial performance. This research proposes that there exists an integrative trust which supports the hypotheses below.

Hypothesis 1. Institutional trust is positively related to empowering interpersonal trust Hypothesis 2. Institutional trust is positively related to enhancing trust in partners

\section{Internal trust and inter-organizational trust}

Some scholars argue that if a manager trusts his/her subordinates, and vice versa, this will create efficient production (Sako, 1992) by reducing the monitoring costs to support the manufacturing process (Bugdol, 2013). The role of trust improves internal management practice, corporate culture, and the organization as a whole (Bieńkowska \& Zabłocka-Kluczka, 2016).

The influence of interpersonal trust has an impact on inter-organizational trust, consisting of two concepts: dispositional and relational trust. Dispositional trust describes the expectation of trust simply in partners in general. Relational trust comes from a relationship with the partners, because trust emerges from the understanding of, and the relations with, a specific exchange companion. Zaheer et al. (1998) emphasize that the relationship between a manager and a partner's manager develops inter-organizational trust. A trusted manager develops inter-organizational trust through an institutionalizing process. During this time, a repeated relationship between two companies becomes more comfortable and more stable, and creates a relationship of collaboration. In this context, the manager - on behalf of the company - represents interpersonal trust, and trusts the partner's manager in relation to the bond between 
the companies. Trust between a manager and his/her partner reduces boundaries between a company and its organizational partners. As a result, the empowered internal trust will increase the trust between the partners (Zaheer et al., 1998). This research proposes that a pleasant climate of interpersonal trust in a company affects the level of inter-organizational trust.

Hypothesis 3: Interpersonal trust has a positive effect on inter-organizational trust

\section{Trust and financial performance}

Companies can expand production through collaboration with business partners or train their workers. When a company calculates the internal costs of staffs' training exceed the external exchange costs in terms of searching for suppliers, negotiating prices, making contracts, and controlling partners, thus a company decides to collaborate with its partners to enhance production. Therefore, a company expands the potential production through collaboration, then will increase the sales of the products or services. As sales increase, profits also rise (Brigham \& Houston, 2019).

Previously, scholars have examined inter-organizational trust as a significant factor (Davis et al., 2000) in boosting business performance (Barney, 2001). However, their results of the effect of trust on business performance are debatable. This study measures business performance in terms of profitability, as it is one of the significant achievements of business performance. Profitability reflects the efficiency of the company in terms of increasing sales while minimizing production costs (Davis et al., 2000). Inter-organizational trust as the proxy of minimizing cost increases profitability as well as raising production and sales. The profitability ratio also indicates how successfully a company can control and apply its resources.

Oláh et al. (2019b) indicated that trust in business partners had a positive influence on financial performance. Besides, trust in management is positively related to a company's financial performance in terms of sales and profits (Davis et al., 2000). On the other hand, trust in a partner also has an inconsistent effect on company performance (Robert W. Palmatier et al., 2006). Furthermore, Johnston et. al. (2004) and Corsten and Felde (2005) concluded that the level of trust had no significant impact on financial performance. This study will propose the hypothesis below.

Hypothesis 4: Inter-organizational trust has a definite influence on financial performance

\section{Inter-organizational trust, innovation, and financial performance}

In a disruptive era, a company should develop an innovative product to compete with rivals by collaborating with partners (Corsten \& Felde, 2005). Trust in partners has a positive effect on resource combinations and exchanges between the collaborating parties, which in turn affects the value creation of product innovation (Tsai \& Ghoshal, 1998). Trust also results in improvements in the product (Jean et al., 2014).

However, the results of the effect of trust on innovation are debatable. One group of researchers argued that inter-organizational trust had a positive influence on innovation (Corsten \& Felde, 2005; Lee et al., 2015; Murphy, 2002). Trust created an innovative process, improved the economic scale and develop sales (Chao, 2011). Besides, trust had a positive and linear relationship with innovation performance (Wang et al., 2011).

The opposing group argued that trust had no direct influence on innovation (Landry et al., 2002). Moreover, trust requires an optimal climate if it is to be positively related to the innovation level. A higher level of trust which exceeds the optimal condition will diminish innovation. In other words, trust is worthwhile, but excessive trust is not a virtue (Molina- 
Morales et al., 2011). Besides, trust does not influence innovation (Landry et al., 2002). This study will propose the fifth hypothesis below.

Hypothesis 5. A higher level of trust in a partner may create an innovation capability.

A positive relationship between trust and innovation was reported by previous results from Corsten \& Felde (2005), Lee et al. (2015), and Murphy (2002). Subsequently, innovation develops product performance, which had a positive influence on financial performance (Vaccaro et al., 2010) in terms of asset specificity (Baye \& Prince, 2017; Williamson, 1993b). This research will propose the hypothesis to support the idea that innovation has a positive effect on financial performance.

Hypothesis 6. Innovation capability may enhance financial performance.

\section{Methodological approach}

\section{Population and sample}

The study population was predominantly made up of ICT companies active in Hungary which have a collaborative partnership with business associates. The study analyzed about 90 per cent of active ICT Companies, i.e. 1625 of 1800. Most of the ICT companies are in Budapest. The other companies are located in cities such as Debrecen, Budaors, Szekesfehervar, Szeged, Gyor, Nyireghaza, among others. This study used random cluster sampling based on the addresses of ICT Companies. The common characteristic of these samples are active operation, being located mostly in Budapest and other cities in Hungary, and having at least one collaboration with a partner. We recently conducted an online survey by submitting a questionnaire to company founders and / or managers as critical informants and respected sources. This survey resulted in 156 samples from 250 questionnaires. The study then excluded outliers from previous samples. The outliers illustrated the samples had a loss, and then we included the samples that had profit and finally used 103 samples. We analyzed the significance level of 10 percent. According to Hair Jr et al. (2016, p. 26), the model having a maximum of six paths direction could include 106 samples. Thus, we assumed the number of our samples is appropriate. We reckoned that our samples represented the population because those samples were existed mostly in Budapest, at about $75 \%$. Those surveyed ICT firms also sited in Pest, Győr-Moson-Sopron, Csongrád, Hajdú-Bihar, Baranya, Békés, Borsod-Abaúj-Zemplén, Komárom-Esztergom, Fejér, Heves, Somogy, Tolna, Vas, and Zala

\section{Variables and operational definition}

The research model comprises five latent variables derived from previous studies. The simplest model consists solely of institutional trust, interpersonal trust, inter-organizational trust, innovation capability, and financial performance. We present the observed variables, as shown in Table 1. 
Table 1. Variables and operational definition

Latent Variables Definition
Interpersonal Trust (IPT) defines
employees' willingness to trust in
managers and the company's
organization (Davis et al., 2000;
Oláh et al., 2017). The employees
trust in the managers will perform
competently establishing decisions
that affect a conducive corporate
culture and trust atmosphere within
a company (Brown et al., 2011;
Sankowska, 2013).
Inter-organizational Trust (IOT)
represents the declaration of
confidence between the company
and the business partners (Wei et al.,
2012), clients and contractors, and
the networks. The company believes
that they will comply with the
promises (Jean et al., 2014), behave
or respond in a predictable and
mutually acceptable manner. The
company trusts the business
relationship by providing benefits
and making the contract effective
due to its important character (Cao
et al., 2017).

Institutional trust (IT) refers to the company's trust in the government (Putnam, 1995; Bursian et al., 2015) and various institutions (Askvik \& Jamil, 2013). The company believes that government and public institutions can independently perform public services due to their professional and expertise capabilities (Askvik \& Jamil, 2013; Vasa et al., 2014; Bursian et al., 2015; Oláh et al., 2019b).

Items

\begin{tabular}{llll}
\multicolumn{4}{l}{ Indicators of Latent Variables } \\
(1) trust between employees and
\end{tabular}

managers/subordinates, as well as the relationships among the owners and management, and also confidence between employees in the same situation (Davis et al., 2000; Oláh et al., 2017),

IPT2 (2) a decisive role in creating a corporate culture and a climate of trust (Sankowska, 2013),

\begin{tabular}{|c|c|}
\hline IPT3 & $\begin{array}{l}\text { (3) rating of managerial style at the company (Brown } \\
\text { et al., 2011), }\end{array}$ \\
\hline IPT4 & $\begin{array}{l}\text { (4) level of staff turnover in the company (Vanhala \& } \\
\text { Dietz, 2015). }\end{array}$ \\
\hline IOT1 & $\begin{array}{l}\text { (1) the level of trust in a business partner (Wei et al., } \\
2012 \text { ); }\end{array}$ \\
\hline IOT2 & (2) the degree of trust in customers and clients, \\
\hline IOT3 & (3) the extent of trust in suppliers and subcontractors, \\
\hline IOT4 & $\begin{array}{l}\text { (4) the degree of trust in other IT providers similar to } \\
\text { the company (Jean et al., 2014); }\end{array}$ \\
\hline IOT5 & $\begin{array}{l}\text { (5) the consideration of the duration of relationships } \\
\text { with the clients, from short term to long term, }\end{array}$ \\
\hline IOT6 & $\begin{array}{l}\text { (6) the evaluation of the beneficial degree of the } \\
\text { company's relationships with contracting partners (Cao } \\
\text { et al., 2017), }\end{array}$ \\
\hline IOT7 & $\begin{array}{l}\text { (7) time for processing in terms of a contract with } \\
\text { clients (Balboni et al., 2018), }\end{array}$ \\
\hline IOT8 & $\begin{array}{l}\text { (8) the company's role as decisive in building trust } \\
\text { between the company and partner companies (Mari, } \\
2010 \text { ) }\end{array}$ \\
\hline IT1 & $\begin{array}{l}\text { (1) the level of trust in state government, ministries, } \\
\text { government agencies (Khan et al., 2019), }\end{array}$ \\
\hline
\end{tabular}

IT2 (2) the degree of trust in the state administration (public procurement office, competition office, the national bank, and others),

IT3 (3) the extent of trust in the courts, the judiciary, and the prosecutor's office,

IT4 (4) the level of trust in politicians,

IT5 (5) trust in local government,

IT6 (6) trust in the chambers of commerce,

IT7 (7) trust in banks (Khan et al., 2019),

IT8 (8) trust in large firms,

IT9 (9) trust in small firms,

IT10 (10) trust in customers, and

IT11 (11) trust in current business partners (Askvik \& Jamil, 2013; Vasa et al., 2014; Bursian et al., 2015; Oláh et al., 2019b)

\begin{tabular}{lll}
\hline $\begin{array}{l}\text { Innovation (IN) describes the } \\
\text { company's competencies to develop } \\
\text { distinctive products that sustained }\end{array}$ & IN1 & $\begin{array}{l}\text { (1) } \begin{array}{l}\text { The degree of innovation in the company's } \\
\text { products and services is high compared to competitors } \\
\text { (Lee et al., 2015), }\end{array} \\
\text { market demand (Jean et al., 2014; }\end{array}$ \\
$\begin{array}{l}\text { Lee et al., 2015). The company } \\
\text { enhances innovation prospects }\end{array}$ & IN3 & $\begin{array}{l}(2) \text { The level of customization to distinct } \\
\text { customer requirements is high compared to } \\
\text { competitors, } \\
\text { through implementing advanced } \\
\text { production systems and innovative }\end{array}$ \\
$\begin{array}{l}\text { (3) The extent of the uniqueness of the company's } \\
\text { products and services is greater than that of its rivals } \\
\text { (Jean et al., 2014), }\end{array}$
\end{tabular}




\begin{tabular}{|c|c|c|}
\hline \multirow[t]{3}{*}{$\begin{array}{l}\text { competitors (Maurer, 2010; Molina- } \\
\text { Morales et al., 2011; Sankowska, } \\
\text { 2013). }\end{array}$} & IN4 & $\begin{array}{l}\text { (4) The company is more innovative than competitors } \\
\text { in deciding what methods to use in achieving targets } \\
\text { and objectives (Molina-Morales et al., 2011), }\end{array}$ \\
\hline & IN5 & $\begin{array}{l}\text { (5) The company is more innovative than rivals in } \\
\text { initiating new procedures or systems (Maurer, 2010), } \\
\text { and }\end{array}$ \\
\hline & IN6 & $\begin{array}{l}\text { (6) The company is more innovative than competitors } \\
\text { in initiating changes in the job content and work } \\
\text { methods of the staff (Molina-Morales et al., 2011; } \\
\text { Sankowska, 2013). }\end{array}$ \\
\hline \multirow{6}{*}{$\begin{array}{l}\text { Financial Performance (FP) denotes } \\
\text { the capabilities of the company } \\
\text { generating profit based on the assets } \\
\text { and capital employed (Brigham \& } \\
\text { Houston, 2019; Oláh et al., 2019b) }\end{array}$} & & $\begin{array}{l}\text { This research utilizes profitability ratios to indicate } \\
\text { financial performance. Profitability ratios consist of: }\end{array}$ \\
\hline & FP1 & (1) Return on Assets (ROA), \\
\hline & FP2 & (2) Return on Equity (ROE), \\
\hline & FP3 & (3) Return on Sales (ROS), \\
\hline & FP4 & (4) Return on Capital Employed (ROCE), and \\
\hline & FP5 & $\begin{array}{l}\text { (5) Operating Profit Margin (OPM) (Brigham \& } \\
\text { Houston, 2019; Oláh et al., 2019b). }\end{array}$ \\
\hline
\end{tabular}

\section{Source: Authors' own compilation}

We measured each question of trust on a five scale range, ranging from very low to very high. On the innovation scale, responses to the survey were given on a 5-point scale, from strongly disagree to strongly agree. Another variable, financial performance, was assessed by a ratio scale. In this research, we formed inter-organizational trust, and innovation as reflective indicators, then interpersonal trust, institutional trust, and financial performance as a formative construct. As a consequence, the assessment of each construct uses a different approach.

\section{Methods}

This research applied a Partial Least Square Structural Equation Model (PLS-SEM) to examine a proposed model, because PLS-SEM is a powerful method to assess the representations of the constructs by weighting composites of the measured indicators. The weighted aggregated indicators represent proxies for measurement error. In addition, this also generates a single precise result for each composite for each examination (Hair et al., 2019; Hair Jr et al., 2016; Ravand \& Baghaei, 2016). A path model in this study comprises an inner model and an outer model. The inner model denotes the associations between latent variables and their indicators. Meanwhile, the outer model denotes the directions between the latent variables: institutional trust, interpersonal trust, inter-organizational trust, innovation capability, and financial performance, as shown in Figure 1. This research constructs institutional trust, interpersonal trust, and financial performance on formative measurements, while inter-organizational trust and innovation are constructed as reflective indicators (Hair Jr et al., 2016).

The research employed Confirmatory Factor Analysis (CFA) to acquire significant indicators from each construct. This is a decisive step to confirm the factors before running the PLS-SEM analysis to examine the correlation between the observed construct and latent variables. The cut-off point is 0.5 for each indicator in each latent variable. Based on the cutoff point, this research will omit the indicators which do not contribute significantly to the latent variables (Hair Jr et al., 2016). We then employed significant indicators as listed in Table AI.1 in the Appendix. 


\section{Conducting the research and its results}

Table 2 describes the surveyed respondents regarding their profession and highest educational level. The main thing to note is that most of the respondents were managers, followed by middle managers, with a minority working as junior managers. Furthermore, most of the respondents had graduated from university. The number of those with a further education college certificate was half of the number of those who were university graduates. The percentage of managers with a higher education certificate was the highest, at about 34 per cent, which was double the number of junior managers with a similar educational level. The number of managers with a further education college certificate was half that of the number of managers with a university degree. The lowest number of respondents were those who had graduated from secondary school.

Table 2. Respondent profile

\begin{tabular}{lcccc}
\hline & \multicolumn{3}{c}{ Educational Level } & Total \\
\cline { 2 - 4 } Position & College & Secondary & University & \\
\hline Junior & 3 & 0 & 11 & 14 \\
\hline Middle manager & 12 & 2 & 22 & 36 \\
\hline Manager & 16 & 2 & 35 & 53 \\
\hline Total & 31 & 4 & 68 & 103 \\
\hline
\end{tabular}

Source: Authors' own data. $n=103$

Table 3. Company report

\begin{tabular}{lc}
\hline Company Age & Frequency \\
\hline Between 1 and 10 years & 13 \\
\hline Between 10 and 20 years & 47 \\
\hline Between 20 and 30 years & 38 \\
\hline More than 30 years & 5 \\
\hline & \\
\hline Firm Assets & 54 \\
\hline Less than 1 Million Euro & 26 \\
\hline Between 1 and 3 Million Euro & 12 \\
\hline Between 3 and 5 Million Euro & 11 \\
\hline More than 5 Million Euro &
\end{tabular}

Source: Authors' own data. $n=103$

Table 3 illustrates the firms' profiles in terms of age and assets. The most typical age of a company was between ten and twenty years, making up about 45 per cent of the total. The next most typical was companies established between 20 and 30 years ago, at about 8 per cent less than the first group. Next came companies which had been running for ten years, at about 12 per cent. Finally, only a few firms had been operating for more than 30 years. The typical value of the assets owned by the companies was below one million Euro. Companies with assets from one to three million Euro were half as typical as the first group. Finally, companies with assets between 3 and 5 million were similar in number to firms with assets of more than five million Euro.

\subsection{Constructs assessment}

We examined the proposed model, based on the measurement and structural models. First, we analyzed the measurement of the construct regarding the reliability, validity, variances 
of the indicators, and collinearity. After this, we also analyzed the structural model in terms of the goodness of fit, the path coefficient of regression, the coefficient of determination, and mediation path analysis (Hair et al., 2019; Tenenhaus et al., 2005).

We conducted a reliable evaluation of inter-organizational trust and innovation by way of reflective constructs. We had previously examined the loading factors for indicators from IOT and I, which were above 0.50 as a minimum rule of thumb for each indicator, as shown in Table AI. 1 in the Appendix. All the loading factors were higher than 0.6. Then, we also checked the internal consistency ratio with Cronbach's Alpha (CA). Table 4 shows that the Cronbach's Alpha (CA) coefficients of inter-organizational trust and innovation were greater than 0.7. We also indicated that the value of Dillon-Goldstein (D.G.) rho for inter-organizational and innovation was above 0.7 as the rule of thumb. Finally, we concluded that inter-organizational trust and innovation met the internal consistency requirement.

In terms of the validity of the construct, we noted that the average variance extracted (AVE) for inter-organizational and innovation was higher than 0.5. Consequently, we concluded that inter-organizational and innovation met the convergent validity assumption. Then, we also showed that inter-organizational and innovation reflected the discriminant validity because the AVE values were higher than any correlations with any other constructs, as shown in the Appendix in Table AI.2.

Table 4. Reliability, variance, and VIF summary

\begin{tabular}{cccccc}
\hline $\begin{array}{c}\text { Latent } \\
\text { variables }\end{array}$ & Indicators & CA & D.G. rho & AVE & VIF \\
\hline IPT & 2 & 0.46 & 0.79 & 0.64 & 1 \\
\hline IOT & 4 & 0.70 & 0.82 & 0.50 & 1.021 \\
\hline IT & 3 & 0.89 & 0.93 & 0.15 & 1 \\
\hline IN & 4 & 0.83 & 0.89 & 0.67 & 1 \\
\hline FP & 3 & 0.93 & 0.95 & 0.76 & 1.005 \\
\hline
\end{tabular}

Source: Authors' own data. $n=103$. IT = Institutional trust, IPT = Interpersonal trust, IOT = Inter-organizational trust, $I N=$ Innovation, $F P=$ Financial performance .

Next, we also examined interpersonal trust, institutional trust, and financial performance as formative constructs. The examination of formative measurement consists of reliability, convergent validity, collinearity, and significant weight (Hair et al., 2019; Ravand \& Baghaei, 2016). We assumed that interpersonal trust, institutional trust, and financial performance were internally consistent because of their D.G. rho values, which were above 0.7 .

We then examined the convergent validity of the construct regarding the values of factor correlations for each construct with a 0.7 rule of thumb. We noticed that the indicators of interpersonal trust, institutional trust, and financial performance had factor correlations above 0.8, as illustrated in Table AI.1 in the Appendix. As a result, we considered that all the measured variables of interpersonal trust, institutional trust, and financial performance met the convergent validity condition. All the indicators of interpersonal trust, institutional trust, and financial performance had a Variance Inflation Factor (VIF) value of below three. We concluded that the aforesaid measured variables did not correlate with each other. This implied that the observed variables met the non-collinearity assumption. Based on the significant weight dimension, we established that all the measured variables were significant, except for IPT 1 in the Table AI.3. 


\subsection{Structural Model Assessment}

We first examined the structural model relating to the Goodness of Fit (GoF). The result of the GoF is illustrated in Table 5.

Table 5. The goodness of model fit

\begin{tabular}{lcccc}
\hline Model & GoF & GoF (Bootstrap) & Standard error & Critical ratio (CR) \\
\hline Outer model & 0.88 & 0.84 & 0.059 & 15.17 \\
\hline Inner model & 0.66 & 0.67 & 0.061 & 10.73 \\
\hline
\end{tabular}

Source: Authors' own data. $n=103$

The goodness of fit (GoF) indicates an overall measure of model fit for PLS-SEM (Hair Jr et al., 2016; Henseler \& Sarstedt, 2013). The suggested cut-off point is 0.60 (Ravand \& Baghaei, 2016; Sanchez et al., 2013). We evaluated the goodness of the model using GoF. Table 5 shows that the inner model had a value of GoF at about 0.7. Thus, we concluded that our model represented the good associations between the latent variables and their indicators. We also obtained the GoF of the outer model at 0.88 . Therefore, we assumed the model had good path directions between the latent variables. We reckoned the model had a satisfactory inner and outer model. As a result, the regression path of the hypotheses is presented in Figure 1.

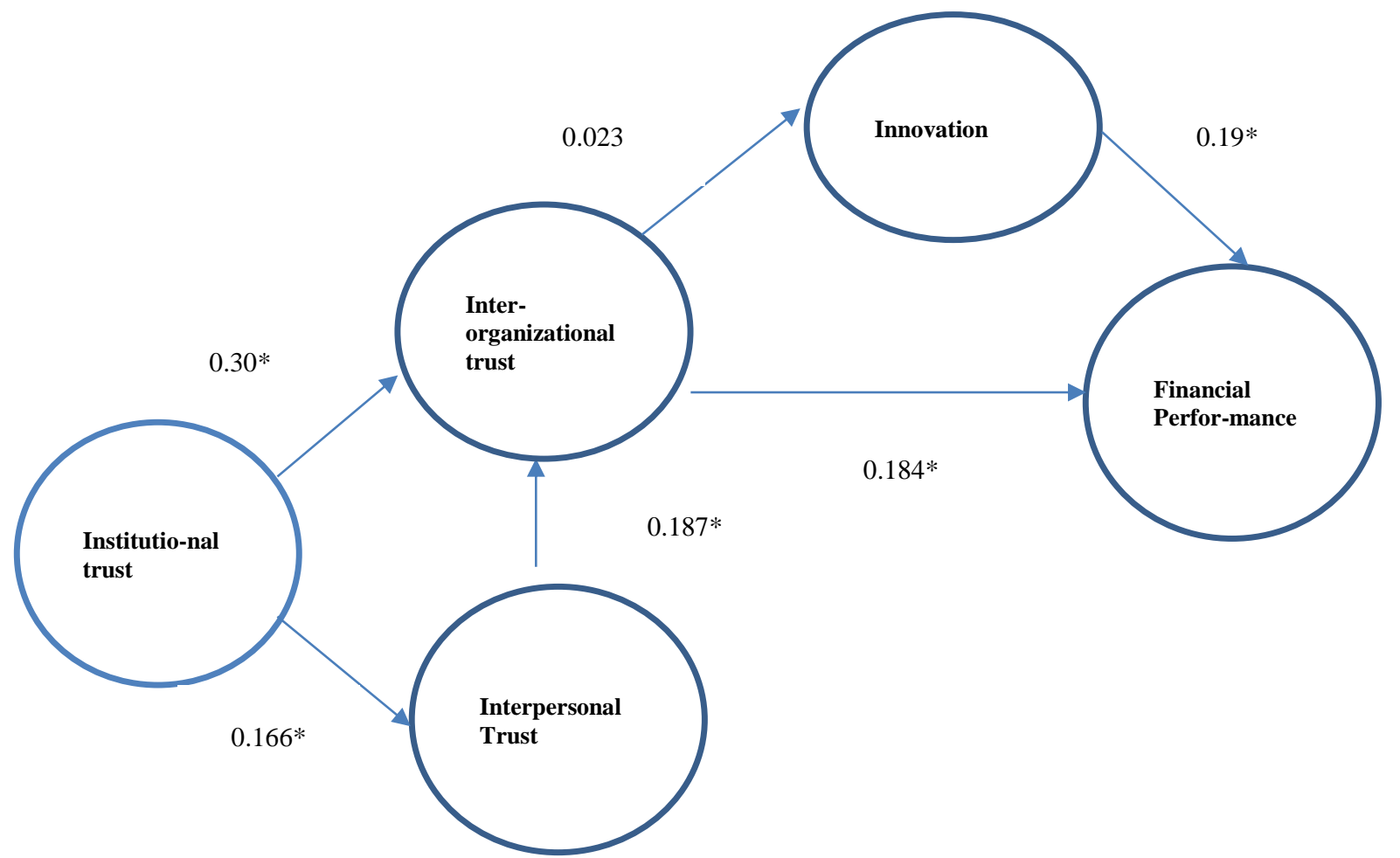

Figure 1. Integrative Trust, Innovation, and Financial Performance Model.

Source: Authors' own data. $n=103$; *) significant below $10 \%$.

In this study, we proposed six hypotheses. The results appear to make sense and to be compatible with our expectations. The results of the regression path and the coefficient of determination are shown in Table 6. 
Table 6. Path coefficient and $\mathrm{R}^{2}$

\begin{tabular}{ccccccc}
\hline Hypothesis & Coefficient & t-stat & Probability & Predictor(s) & Outcome & $\mathrm{R}^{2}$ \\
\hline $\begin{array}{c}\text { H1: IT } \rightarrow \\
\text { IPT }\end{array}$ & 0.166 & 1.690 & $0.094 *$ & IT & IPT & 0.028 \\
H2: IT $\rightarrow$ & 0.301 & 3.212 & $0.002 *$ & IT and IPT & IOT & 0.144 \\
IOT & & & & & & \\
H3: IPT $\rightarrow$ & 0.187 & 1.989 & $0.049 *$ & IOT & IN & 0 \\
$\quad$ IOT & & & & & & \\
H4: IOT $\rightarrow$ & 0.184 & 1.903 & $0.060 *$ & IOT and IN & FP & 0.071 \\
$\quad$ FP & & & & & \\
H5: IOT $\rightarrow$ \\
$\quad$ IN
\end{tabular}

Source: Authors' own data. $\left.n=103 ;{ }^{*}\right)$ significant below 10\%. IT = Institutional trust, IPT $=$ Interpersonal trust, $I O T=$ Inter-organizational trust, $I N=$ Innovation, $F P=$ Financial performance.

This study contributes to the literature combined with previous studies. This research has established a strong, positive relationship between institutional trust and interpersonal trust, confirming the perspective of institutional trust as a guarantee and developer of the internal business climate within a company. The result shows that institutional trust has a positive effect on interpersonal trust within a company. From a social capital perspective, institutional trust encourages managers and employees to perform within an organization more positively in order to achieve collective goals. Institutional trust simplifies the internal coordination and cooperation between the manager and employees to their mutual advantage in the company (Putnam, 1995). The finding of this study confirmed previous observations that confidence in institutions influenced interpersonal trust (Brehm \& Rahn, 1997; Levi, 1996). This result relates to the strong relationship in which a higher level of institutional performance indicates an increase in interpersonal trust, as was previously explored by Brehm and Rahn (1997). Our approach was not comparable to the results of Lim et al. (2016), who investigated the path of interpersonal trust on trust in institutions.

In this research, institutional trust reveals a 2.8 per cent variability in interpersonal trust. Therefore, we consider that the low coefficient determinant for this relationship proves that there may be other factors beyond institutional trust that are essential to nurturing interpersonal trust. Two studies have investigated the sources of interpersonal trust within the company in terms of the cognitive basis and affective basis of trust. For instance, McAllister (1995) examined the idea that colleagues' consistent responsibility for accomplishment had a significant influence on interpersonal trust from a cognitive basis perspective. Furthermore, he also revealed that regular relations, partners' acts of affiliation, and the forms of social responsibility adopted by subordinates fostered interpersonal trust in terms of affective-based trust. Moreover, Costigan et. al. (1998) also showed correspondingly that dyadic connection, enthusiasm, confidence, manners, personal initiative, the career promotion system and objective assessment, and effective remuneration as a reward for work determined interpersonal trust from the perspective of affective-based trust.

The next significant result of this study relates to the impact of interpersonal trust on inter-organizational trust. We reveal the significance of interpersonal trust in enhancing trust in business partners. This result supports the experiment by Zaheer et al. (1998) related to micromacro inter-organizational networks. The connection between the manager and his/her partners is usually set up through informal interpersonal relationships (Inkpen \& Tsang, 2005; Sroka, 2011). Following this, the connectivity between managers and corporate affiliates may develop 
into a relationship (Inkpen \& Tsang, 2005). As a result, the manager, acting on behalf of the company, trusts directly in partners in an inclusive approach. Inter-organizational trust originates from an interpersonal relationship between the manager and his/her associates, and can be explained as follows. During this time, the recurrent affiliation between two representatives of each company matures more securely and steadily in creating an engagement of collaboration (Zaheer et al., 1998). The result showed that interpersonal and interorganizational trust were correlated. This connection affected cooperation processes (Zaheer et al., 1998), assists in partnership forming, and diminishes transaction costs (Niazi \& Hassan, 2016). From the transaction cost perspective, a company increased production throughout the partnership with the business partners, as the internal exchange cost surpasses the external exchange cost (Brigham \& Houston, 2019). Indeed, trust between organizations improved the flexibility of mutual relationships. Inter-organizational trust also shortened adaptation time, improved product and process quality, reduced the cost of coordination activities (Smith et al., 1995), lessened the uncertainty of cooperation and - importantly - diminished interaction costs (Mu et al., 2008).

We also proved that interpersonal trust fully mediated the influence of institutional trust on inter-organizational trust. This study reinforced the idea that interpersonal trust has a role as a complementary mediating variable. This outcome supported previous research from Brehm \& Rahn (1997), who revealed that trust in government and various institutions could be a simplification of interpersonal trust (Brehm \& Rahn, 1997) to perform essential business collaborations.

This research also emphasized the finding that institutional trust and interpersonal trust strengthened inter-organizational trust by about 14 per cent. This was remarkable in a country with a low level of trust, such as Hungary (Sroka, 2011). Indeed, other factors connected with the reinforcement of inter-organizational trust were also revealed in previous studies, for instance, reliability and integrity, and qualities related to factors such as consistency, competency, honesty, fairness, responsibility, helpfulness, and benevolence (Morgan \& Hunt, 1994). Besides, knowledge intensity and uncertainty also affected trust in business partners' maturity (Gaur et al., 2011).

The relationship between inter-organizational trust and business performance contributed to the debate among scholars. We support that inter-organizational trust improves financial performance as the proxy of business performance. As expected, the finding of this study supports previous researchers, such as Fang et al. (2008), Bien, Ben, and Wang (2014), Gaur et al. (2011), Wei et al. (2012), Shahmehr et al. (2015), and Moeller (2009), i.e. that interorganizational trust enhanced financial performance.

From a transaction cost perspective, a company expands production by comparing internal exchange costs and external exchange costs. When the company predicts that external exchange costs will be less than internal exchange costs, the company decides to collaborate with its business partners, in improving production. In the collaboration context, trust operates as a hierarchical governance to push partners to reach an agreement (R. Galford \& A. S. Drapeau, 2003; Inkpen \& Tsang, 2005; Tsai \& Ghoshal, 1998) to support the company's production. As a result, improving production while minimizing costs improves sales, as well as the profit related to the financial performance. Our finding substantially supported the previous results which found that a higher level of trust in a partner (Robert Galford \& Anne Seibold Drapeau, 2003) has a definite impact on the direction of business performance (Allen et al., 2018; Davis et al., 2000; Dyer \& Chu, 2003; Iancu \& Nedelea, 2018).

On the other hand, the result of this study contradicts researchers who argued that trust in colleagues had an inconsistent effect on company performance (Robert W. Palmatier et. al. 2018). Johnston et al. (2004) concluded that the level of trust in business partners had no 
significant impact on company performance. Besides, confidence in a business partner did not directly affect business performance (Al-Hakim \& Lu, 2017). This result likewise contradicted that of Moeller (2009), who revealed that trust had no clear effects on financial performance.

Our next result does not support the proposed hypothesis in this research, i.e. that interorganizational trust has a positive influence on innovation. Comparing this with the results of Corsten and Felde (2005) and Tsai et al. (2010), there is a contradictive direction between trust and innovation. To further the debate, we consider that other factors besides trust in partners affect innovation directly. Scholars have previously argued that the budget for research and development (Capon et al., 1992), inter-functional coordination and human resource practices (Suseno \& Ratten, 2007), a rapid response to information from the marketplace, and science and technology (Darroch \& McNaughton, 2002) encourage improvements in the innovation level. We also consider intermediate factors such as working in partnership with international customers, using technology to disseminate knowledge, responding to knowledge about technology, and being flexible and opportunistic (Kitchell, 1995) to be important.

Our result indicated that innovation was significantly associated with financial performance. This result was essentially confirmed in the research by Vaccaro et al. (2010), and Zaheer et al. (1998). Besides innovation, we also agree that strategic relevance and participation in the network has a great impact on financial performance (Moeller, 2009). Indeed, quality improvement and cost improvement are equally significantly interrelated with financial performance (Maiga \& Jacobs, 2007). We proposed that innovation mediated the direction between inter-organizational trust and financial performance. However, innovation failed to mediate the influence of inter-organizational trust on financial performance. As a significant point, we revealed that inter-organizational trust and innovation explained about 7 per cent of the variability in financial performance. From the perspective of social capital, we can establish a significant pathway in that trust and trustworthiness were found to be positively associated with resource exchange and combination. Consequently, resource exchanges and combinations create value for firms through significant, positive effects on product innovations (Tsai \& Ghoshal, 1998). Besides, we also support the idea that building social capital is related to enhanced business knowledge and innovation performance in similar European countries, such as Denmark, Ireland and Wales (Cooke \& Wills, 1999).

Our finding implies that a company should develop shared relationship bonds, trust in partners, and mutuality significantly associated with knowledge sharing intentions, in order to achieve innovation (Akhavan \& Mahdi Hosseini, 2016) and to deal with business pressure in a disruptive period.

After discussing the path coefficient result, we also investigated the direct and indirect effects of the model. This study has two types of moderating variable. First, interpersonal trust as a mediating variable to empower the influence of institutional trust on inter-organizational trust. Following this, innovation is proposed as a mediating variable to enhance the impact of inter-organizational trust on financial performance. We scrutinized the significance of a direct, indirect, and total effect to explain the role of interpersonal trust and innovation, as shown in Table 7.

Interpersonal trust has a role as a complementary mediating variable. This implies that interpersonal trust has a similar effect to institutional trust. Interpersonal trust has significantly mediated the influence of institutional trust on inter-organizational trust. Meanwhile, innovation has failed to mediate the influence of inter-organizational trust on financial performance. However, moving in the same direction, innovation improves financial performance as well as inter-organizational trust. This implies the need to consider the variables which may replace or empower innovation in forthcoming research. 
Table 7. Direct and indirect effects of observed variables

\begin{tabular}{ccccc}
\hline Direction & Effect & Value & $\begin{array}{c}\text { Significance of } \\
\text { Coefficient }\end{array}$ & $\begin{array}{c}\text { Justification of the } \\
\text { mediating variable }\end{array}$ \\
\hline $\begin{array}{c}\text { IT } \rightarrow \text { IPT } \rightarrow \\
\text { IOT }\end{array}$ & Indirect & 0.0012 & $\begin{array}{c}\text { All coefficients are } \\
\text { significant }\end{array}$ & $\begin{array}{c}\text { Complementary } \\
\text { (partial mediation) }\end{array}$
\end{tabular}

\begin{tabular}{|c|c|c|c|c|}
\hline $\mathrm{IT} \rightarrow \mathrm{IOT}$ & Direct & 0.1001 & & \\
\hline & Total & 0.1013 & & \\
\hline $\begin{array}{c}\text { IOT } \rightarrow \text { IN } \rightarrow \\
\text { FP }\end{array}$ & Indirect & 0 & \multirow{2}{*}{$\begin{array}{l}\text { IOT to IN is not } \\
\text { significant; IN to } \\
\text { FP is significant; } \\
\text { IOT to FP is } \\
\text { significant }\end{array}$} & $\begin{array}{c}\text { Direct only (no } \\
\text { mediation) }\end{array}$ \\
\hline IOT $\rightarrow$ FP & Direct & 0.0345 & & \\
\hline & Total & 0.0345 & & \\
\hline
\end{tabular}

Source: Authors' own data. $n=103 . I T=$ Institutional trust, $I P T=$ Interpersonal trust, $I O T=$ Inter-organizational trust, $I N=$ Innovation, $F P=$ Financial performance .

\subsection{Implications for theory and practice}

This study is novel in describing a new perspective of integrative trust to improve financial performance. This study confirms the previous studies which argue that institutional trust contributes to enhancing interpersonal trust and inter-organizational trust. Interpersonal also operates as a complementary mediating variable to influence inter-organizational trust, which in turn improves financial performance. Although this study does not support the influence of inter-organizational on innovation, it shows that innovation improves financial performance.

This study further extends the discussion of trust as consolidative social capital to improve financial performance. A coincident trust supports business, with the further explanation that institutional trust as an external cause strengthens interpersonal trust within a company. Institutional trust also strengthens the confidence between the company and business partners to support collaboration. Inter-organizational trust also improves financial performance. Our study also explains the research gap around the question of whether trust in partners has a positive effect on business performance. In addition, it also supports previous scholars who have argued that innovation improves financial performance.

According to the indicators which a have high loading factor, we initially recommend that firms and managers consider maintaining interpersonal trust in terms of developing trust between staff and supervisors, together with the connection between shareholders and management. Managers should maintain confidence between employees and their colleagues in the company (Davis et al., 2000; Oláh et al., 2017). Trust among employees creates effectiveness and cohesion in the company organization. The staff and their partners work together as a team, share information, become engaged in rights and responsibilities, and cooperate. Trust between employees and workmates develops talents and capability. As a result, a company can achieve significant objectives. Hence, managers should have a significant role in creating a corporate culture conducive to supporting the climate of trust within a company (Sankowska, 2013). Managers should develop interpersonal trust as an essential element in providing an influential corporate culture which ensures a sense of trustworthiness. As a consequence, employees feel safe in speaking openly, taking advantage of appropriate situations, and revealing deficiencies, in order to achieve the company's targets.

Another recommendation is that managers should enhance the confidence level of customers and clients because they are the primary resources. Without them, the business would 
not run well. The company should retain its clients and develop a relationship with them by approaches involving trust. When customers maintain trust, a company can increase its business reputation and provide value-added to its clients. Besides, a company should also emphasis maintaining trust in suppliers, because the firm may acquire genuine benefits. A relationship of trust in suppliers provides the company access to potential resources. Contractors support the company's production through committed service, favorable prices, and exceptional conditions. As a result, the company minimizes external transaction costs and so enhance its manufacturing.

In line with a high level of interpersonal trust, trust in clients, and in suppliers, a company also should innovate its products and services in competition with its rivals. Innovation is one decisive concern of the company in terms of growth and synchronization in a challenging market (Dabija et al., 2017). As mentioned earlier, a firm develops innovation by implementing new methods and novel procedures or systems to accomplish its targets. As a result, practical innovation enhances productivity and thereby raises profitability, as supported in this study. Finally, the elements of profitability most affected by innovation include ROA, ROE, and ROCE, as verified in this study.

\section{Conclusion}

In summary, this study demonstrated that integrative trust has led to further improvements in financial performance. Naturally, this study provides a valuable concept for examining how inter-organizational trust enriches interpersonal trust and inter-organizational trust. An exciting finding to note here is that interpersonal trust as a paired intermediating variable of institutional trust has an influence on inter-organizational trust. As predicted, interorganizational trust contributes to a significant increase in financial performance. The main limitation, however, is that this research failed to support the influence inter-organizational trust on innovation. As a final point, this finding reinforces the general framework that a rise in financial performance is accompanied by the increasing prevalence of innovation.

We suggest three essential implications. As a first point, managers should pay attention to developing interpersonal trust and levels of confidence in order to support work effectiveness among employees. The subsequent recommendation is that a company can maintain and develop trust in customers as the primary assets. A firm should also consider sustaining trust in suppliers to ensure access to specialized resources. To sum up, we suggest that trust in business partners and innovation may support profitability.

\section{Acknowledgement}

This research was funded by the National Research, Development, and Innovation Fund of Hungary. Project no. 132805 has been implemented with the support provided from the National Research, Development and Innovation Fund of Hungary, financed under the K_19 funding scheme. 


\section{References}

Adler, P. S., \& Kwon, S.-W. (2002). Social capital: Prospects for a new concept. Academy of Management Review, 27(1), 17-40. doi:10.5465/amr.2002.5922314

Afonasova, M. A., Panfilova, E. E., Galichkina, M. A., \& Ślusarczyk, B. (2019). Digitalization in economy and innovation: The effect on social and economic processes. Polish Journal of Management Studies, 19. doi:10.17512/pjms.2019.19.2.02

Akhavan, P., \& Mahdi Hosseini, S. (2016). Social capital, knowledge sharing, and innovation capability: an empirical study of R\&D teams in Iran. Technology Analysis \& Strategic Management, 28(1), 96-113. doi:10.1080/09537325.2015.1072622

Al-Hakim, L., \& Lu, W. (2017). The role of collaboration and technology diffusion on business performance. International Journal of Productivity and Performance Management, 66(1), 22-50. doi:10.1108/IJPPM-08-2014-0122

Allen, M. R., George, B. A., \& Davis, J. H. (2018). A model for the role of trust in firm level performance: The case of family businesses. Journal of Business Research, 84, 34-45. doi:10.1016/j.jbusres.2017.10.048

Almășan, A., Circa, C., Dumitru, M., Gușe, R. G., \& Mangiuc, D. M. (2019). Effects of Integrated Reporting on Corporate Disclosure Practices regarding the Capitals and Performance. Amfiteatru Economic, 21(52), 572-589. doi:10.24818/EA/2019/52/572

Almási, Zs. B., \& Zéman, Z. (2019). Macroeconomic growth in business valuation. Economic Annals-XXI 175 (1-2) 18-23.

Askvik, S., \& Jamil, I. (2013). The institutional trust paradox in Bangladesh. Public Organization Review, 13(4), 459-476. doi:10.1007/s11115-013-0263-6

Ayu, M., Gamayuni, R. R., \& Urbański, M. (2020). The impact of environmental and social costs disclosure on financial performance mediating by earning management. Polish Journal of Management Studies, 21(2), 74-86. doi:10.17512/pjms.2020.21.2.06

Balboni, B., Marchi, G., \& Vignola, M. (2018). The Moderating Effect of Trust on Formal Control Mechanisms in International Alliances. European Management Review, 15(4), 541-558. doi:10.1111/emre.12150

Baranyai, Z., Gyuricza, C., \& Vasa, L. (2012). Moral Hazard Problem and Cooperation Willingness: some Experiences from Hungary. Actual Problems of Economics (138), 301-310. doi:10.1080/08974438.2013.833567

Barney, J. B. (2001). Resource-based theories of competitive advantage: A ten-year retrospective on the resource-based view. Journal of Management, 27(6), 643-650. doi:10.1177/014920630102700602

Baye, M. R., \& Prince, J. T. (2017). Managerial Economics and Business Strategy, Ninth Edition. New York: McGraw-Hill Education.

Bien, H.-J., Ben, T.-M., \& Wang, K.-F. (2014). Trust relationships within R\&D networks: A case study from the biotechnological industry. Innovation, 16(3), 354-373. doi:10.1080/14479338.2014.11081993

Bieńkowska, A., \& Zabłocka-Kluczka, A. (2016). Trust and controlling. Management, 20(2), 261-277. doi:10.1515/manment-2015-0064

Bilan, S., Mishchuk, H., Samoliuk, N., \& Ostasz, G. (2020). Effectiveness of Social Dialogue in the System of Sustainable Economic Development Factors. Paper presented at the The 34th International Business Information Management Association Conference, IBIMA 2020: Vision 2025: Education Excellence and Management of Innovations through Sustainable Economic Competitive Advantage.

Bilan, Y., Mishchuk, H., Samoliuk, N., \& Grishnova, O. (2019). ICT and Economic Growth: Links and Possibilities of Engaging. Intellectual Economics, 13(1), 93-104. 
Brehm, J., \& Rahn, W. (1997). Individual-level evidence for the causes and consequences of social capital. American Journal of Political Science, 999-1023. doi:10.2307/2111684

Brigham, E. F., \& Houston, J. F. (2019). Fundamentals of Financial Management, Fifteenth Edition. Boston, USA: Cengage Learning, Inc.

Brower, H. H., Lester, S. W., Korsgaard, M. A., \& Dineen, B. R. (2009). A closer look at trust between managers and subordinates: Understanding the effects of both trusting and being trusted on subordinate outcomes. Journal of Management, 35(2), 327-347. doi:10.1177/0149206307312511

Brown, S., McHardy, J., McNabb, R., \& Taylor, K. (2011). Workplace performance, worker commitment, and loyalty. Journal of Economics \& Management Strategy, 20(3), 925955. doi:10.1016/j.jebo.2015.05.001

Bugdol, M. (2013). Selected proposals and possibilities of trust development within the TQM concept. The TQM Journal, 25(1), 75-88. doi:10.1108/17542731311286441

Bursian, D., Weichenrieder, A. J., \& Zimmer, J. (2015). Trust in government and fiscal adjustments. International Tax and Public Finance, 22(4), 663-682. doi:10.1007/s10797015-9363-2

Cao, Q., Schniederjans, D. G., \& Schniederjans, M. (2017). Establishing the use of cloud computing in supply chain management. Operations Management Research, 10(1-2), 47 63. doi:10.1007/s12063-017-0123-6

Capon, N., Farley, J. U., Lehmann, D. R., \& Hulbert, J. M. (1992). Profiles of product innovators among large US manufacturers. Management Science, 38(2), 157-169. doi:10.1287/mnsc.38.2.157

Chao, Y.-C. (2011). Decision-making biases in the alliance life cycle: Implications for alliance failure. Management Decision, 49(3), 350-364. doi:10.1108/00251741111120743

Cooke, P., \& Wills, D. (1999). Small firms, social capital and the enhancement of business performance through innovation programmes. Small Business Economics, 13(3), 219234. doi:10.1023/A:1008178808631

Corsten, D., \& Felde, J. (2005). Exploring the performance effects of key-supplier collaboration. International Journal of Physical Distribution \& Logistics Management, 35(6), 445-461. doi:10.1108/09600030510611666

Costigan, R. D., Iiter, S. S., \& Berman, J. J. (1998). A multi-dimensional study of trust in organizations. Journal of Managerial Issues, 303-317.

Crook, T. R., Combs, J. G., Ketchen Jr, D. J., \& Aguinis, H. (2013). Organizing around transaction costs: What have we learned and where do we go from here? Academy of Management Perspectives, 27(1), 63-79. doi:10.5465/amp.2012.0008.

Cygler, J., \& Sroka, W. (2017, 4th - 5th October 2017). Structural pathologies in interorganizational networks: analysis of the position in the network, network density and links in the network. Paper presented at the the 17th International Scientific Conference "Globalization and Its Socio-Economic Consequences", University of Zilina, The Faculty of Operation and Economics of Transport and Communications.

Dabija, D.-C., Al Pop, N., \& Săniuță, A. (2017). Innovation in do-it-yourself retail: an empirical study on generation $\mathrm{X}$ among professional craftsmen and consumers. Economics \& Sociology, 10(2), 296-311. doi:10.14254/2071-789X.2017/10-2/22

Darroch, J., \& McNaughton, R. (2002). Examining the link between knowledge management practices and types of innovation. Journal of Intellectual Capital. doi:10.1108/14691930210435570

Davis, J. H., Schoorman, F. D., Mayer, R. C., \& Tan, H. H. (2000). The trusted general manager and business unit performance: empirical evidence of a competitive advantage. Strategic 
Management Journal, 21(5), 563-576. doi:10.1002/(SICI)10970266(200005)21:5<563::AID-SMJ99>3.0.CO;2-0

Draskovic, M., Milica, D., Mladen, I., \& Chigisheva, O. (2017). Preference of institutional changes in social and economic development. Journal of International Studies, 10(2), 318-328. doi:10.14254/2071-8330.2017/10-2/22

Dyer, J. H., \& Chu, W. (2003). The role of trustworthiness in reducing transaction costs and improving performance: Empirical evidence from the United States, Japan, and Korea. Organization Science, 14(1), 57-68. doi:10.1287/orsc.14.1.57.12806

EMIS. (2020). EMIS Benchmark Income Statement: Information (51). EMIS In, Or, Emerging Market: www.EMIS.com. Retrieved March 2, 2020, from https://www.emis.com/php/benchmark/sector/indicators?gid=3\&pc=HU\&prod\%5B0\%5 $\mathrm{D}=\mathrm{HU} \& \mathrm{indu}=51 \&$ change_selected_countries $=1 \& \mathrm{c}=\mathrm{EUR}$

Fang, E., Palmatier, R. W., Scheer, L. K., \& Li, N. (2008). Trust at different organizational levels. Journal of Marketing, 72(2), 80-98. doi:10.1509/jmkg.72.2.80

Fukuyama, F. (1995). Trust: The social virtues and the creation of prosperity (Vol. 99).

Fulmer, C. A., \& Gelfand, M. J. (2012). At what level (and in whom) we trust: Trust across multiple organizational levels. Journal of Management, 38(4), 1167-1230. doi: $10.1177 / 0149206312439327$

Galford, R., \& Drapeau, A. S. (2003). The enemies of trust. Harvard Business Review, 81(2), $88-95$.

Gaur, A. S., Mukherjee, D., Gaur, S. S., \& Schmid, F. (2011). Environmental and firm level influences on inter-organizational trust and SME performance. Journal of Management Studies, 48(8), 1752-1781. doi:10.1111/j.1467-6486.2011.01011.x

Goergen, M., Chahine, S., Brewster, C., \& Wood, G. (2013). Trust, owner rights, employee rights and firm performance. Journal of Business Finance \& Accounting, 40(5-6), 589619. doi:10.1111/jbfa. 12033

Hair, J. F., Risher, J. J., Sarstedt, M., \& Ringle, C. M. (2019). When to use and how to report the results of PLS-SEM. European Business Review. doi:10.1108/EBR-11-2018-0203

Hair Jr, J. F., Hult, G. T. M., Ringle, C., \& Sarstedt, M. (2016). A primer on partial least squares structural equation modeling (PLS-SEM): Sage publications.

Henseler, J., \& Sarstedt, M. (2013). Goodness-of-fit indices for partial least squares path modeling. Computational Statistics, 28(2), 565-580. doi:10.1007/s00180-012-0317-1

Iancu, I. A., \& Nedelea, A.-M. (2018). Consumer confidence from Cluj-Napoca metropolitan area, in the food labeling system. Amfiteatru Economic, 20(47), 116-133.

Inkpen, A. C., \& Tsang, E. W. (2005). Social capital, networks, and knowledge transfer. Academy of Management Review, 30(1), 146-165. doi:10.5465/amr.2005.15281445

Jean, R. J. B., Sinkovics, R. R., \& Hiebaum, T. P. (2014). The Effects of Supplier Involvement and Knowledge Protection on Product Innovation in Customer-Supplier Relationships: A Study of Global Automotive Suppliers in China. Journal of Product Innovation Management, 31(1), 98-113. doi:10.1111/jpim.12082

Johnston, D. A., McCutcheon, D. M., Stuart, F. I., \& Kerwood, H. (2004). Effects of supplier trust on performance of cooperative supplier relationships. Journal of Operations Management, 22(1), 23-38. doi:10.1016/j.jom.2003.12.001

Kaasa, A. (2019). Determinants of individual-level social capital: Culture and personal values. Journal of International Studies, 12(1), 9-32.

Kadefors, A. (2004). Trust in project relationships-inside the black box. International Journal of Project Management, 22(3), 175-182. doi:10.1016/S0263-7863(03)00031-0 
Kitchell, S. (1995). Corporate culture, environmental adaptation, and innovation adoption: a qualitative/quantitative approach. Journal of The Academy of Marketing Science, 23(3), 195-205. doi:10.1177/0092070395233004

Kliestik, T., Misankova, M., Valaskova, K., \& Svabova, L. (2018). Bankruptcy prevention: new effort to reflect on legal and social changes. Science and Engineering Ethics, 24(2), 791803. doi:10.1007/s11948-017-9912-4

Kliestikova, J., Misankova, M., \& Kliestik, T. (2017). Bankruptcy in Slovakia: international comparison of the creditor' s position. Oeconomia Copernicana, 8(2).

Ključnikov ${ }^{1}$, A., Mura, L., \& Sklenár, D. (2019). Information security management in SMEs: Factors of success, Entrepreneurship and Sustainability Issues. Entrepreneurship and Sustainability Issues, 6(4), 2081-2094. doi:10.9770/jesi.2019.6.4(37)

Kovacova, M., Kliestik, T., Valaskova, K., Durana, P., \& Juhaszova, Z. (2019). Systematic review of variables applied in bankruptcy prediction models of Visegrad group countries. Oeconomia Copernicana, 10(4), 743-772. doi:10.24136/oc.2019.034

KSH (2020). Value and distribution of gross value added by industry in 2018. Kozponti Statisztikai Hivatal: www.ksh.hu. Retrieved May 13, 2020, from http://www.ksh.hu/docs/eng/xstadat/xstadat_annual/i_qpt002d.html

Landry, R., Amara, N., \& Lamari, M. (2002). Does social capital determine innovation? To what extent? Technological Forecasting and Social Change, 69(7), 681-701. doi:10.1016/S0040-1625(01)00170-6

Lechman, E. (2018). Networks Externalities as Social Phenomenon in the Process ICT Diffusion. Economics and Sociology, 11(1), 22-43.

Lee, Y., Cho, I., \& Park, H. (2015). The effect of collaboration quality on collaboration performance: empirical evidence from manufacturing SMEs in the Republic of Korea. Total Quality Management \& Business Excellence, 26(9-10), 986-1001. doi:10.1080/14783363.2015.1050169

Levi, M. (1996). Social and unsocial capital: A review essay of Robert Putnam's Making Democracy Work. Politics \& Society, 24(1), 45-55. doi:10.1177/0032329296024001005

Lim, D.-H., Oh, J.-M., \& Kwon, G.-H. (2016). Mediating effects of public trust in government on national competitiveness: Evidence from Asian countries. International Review of Public Administration, 21(2), 125-146. doi:10.1080/12294659.2016.1189196

Maiga, A. S., \& Jacobs, F. A. (2007). Activity-based cost management and manufacturing, operational and financial performance: A structural equation modeling approach. Advances in Management Accounting, 16, 217-260. doi:10.1016/S1474-7871(07)160081

Mari, I. (2010). 15 The dynamics of trust across cultures in family firms. Organizational Trust, 383.

Maurer, I. (2010). How to build trust in inter-organizational projects: The impact of project staffing and project rewards on the formation of trust, knowledge acquisition and product innovation. International Journal of Project Management, 28(7), 629-637. doi:10.1016/j.ijproman.2009.11.006

McAllister, D. J. (1995). Affect-and cognition-based trust as foundations for interpersonal cooperation in organizations. Academy of Management Journal, 38(1), 24-59. doi: $10.5465 / 256727$

Meyer, N., \& Meyer, D. F. (2017). Best practice management principles for business chambers to facilitate economic development: evidence from South Africa. Polish Journal of Management Studies, 15(1). doi:10.17512/pjms.2017.15.1.14

Moeller, K. (2009). Intangible and financial performance: causes and effects. Journal of intellectual capital. doi:10.1108/14691930910952632 
Molina-Morales, F. X., Martínez-Fernández, M. T., \& Torlo, V. J. (2011). The dark side of trust: The benefits, costs and optimal levels of trust for innovation performance. Long Range Planning, 44(2), 118-133. doi:10.1016/j.lrp.2011.01.001

Morgan, R. M., \& Hunt, S. D. (1994). The commitment-trust theory of relationship marketing. Journal of Marketing, 58(3), 20-38. doi:10.1177\%2F002224299405800302

$\mathrm{Mu}$, J., Peng, G., \& Love, E. (2008). Interfirm networks, social capital, and knowledge flow. Journal of Knowledge Management.

Mugarura, N. (2016). Different types of guarantee schemes and their usage in safeguarding against default risks in international commercial practice. International Journal of Law and Management, 58(5), 507-522. doi:10.1108/IJLMA-05-2015-0024

Mura, L., Buleca, J., Hajduova, Z., \& Andrejkovic, M. (2015). Quantitative Financial Analysis of Small and Medium Food Enterprises in a Developing Country. Transformations in Business \& Economics, 14(1).

Murphy, J. T. (2002). Networks, trust, and innovation in Tanzania's manufacturing sector. World development, 30(4), 591-619. doi:10.1016/S0305-750X(01)00131-0

Myšková, R., \& Hájek, P. (2019). Relationship between corporate social responsibility in corporate annual reports and financial performance of the US companies. Journal of International Studies, 12(1).

Niazi, A., \& Hassan, H. (2016). Trust and economic performance. Review of International Business and Strategy. doi:10.1108/RIBS-02-2016-0010

Oláh, J., Bai, A., Karmazin, G., Balogh, P., \& Popp, J. (2017). The role played by trust and its effect on the competiveness of logistics service Providers in Hungary. Sustainability, 9(12), 2303. doi:10.3390/su9122303

Oláh, J., Popp, J., Máté, D., \& Hidayat, Y. A. (2019a). Market structure and concentration ratio: Evidence of Information Technology companies in Hungary. Forum Scientiae Oeconomia, 7(3), 7-18. doi:10.23762/FSO_VOL 7_NO 3_1

Oláh, J., Yusmar, A., Máté, D., Novotny, Á., Popp, J., Lakner, Z., \& Kovács, S. (2019b). A trust approach to the financial performance of information and communications technology enterprises. Polish Journal of Management Studies, 20(1). doi:10.17512/pjms.2019.20.1.29

Palmatier, R. W., Dant, R. P., Grewal, D., \& Evans, K. R. (2006). Factors influencing the effectiveness of relationship marketing: a meta-analysis. Journal of Marketing, 70(4), 136-153. doi:10.1509/jmkg.70.4.136

Palmatier, R. W., Dant, R. P., Grewal, D., \& Evans, K. R. (2018). Factors Influencing the Effectiveness of Relationship Marketing: A Meta-Analysis. Journal of Marketing, 70(4), 136-153. doi:10.1509/jmkg.70.4.136

Porta, R. L., Lopez-De-Silane, F., Shleifer, A., \& Vishny, R. W. (1996). Trust in large organizations. National Bureau of Economic Research. doi:10.3386/w5864

Pratono, A. H. (2018). From social network to firm performance. Management Research Review. doi:10.1108/MRR-03-2017-0080

Putnam, R. D. (1995). Tuning in, tuning out: The strange disappearance of social capital in America. PS: Political Science \& Politics, 28(4), 664-683.

Ravand, H., \& Baghaei, P. (2016). Partial least squares structural equation modeling with R. Practical Assessment, Research, and Evaluation, 21(1), 11. doi:10.7275/d2fa-qv48

Revilla, E., \& Knoppen, D. (2015). Building knowledge integration in buyer-supplier relationships. International Journal of Operations \& Production Management. doi:10.1108/IJOPM-01-2014-0030 
Rim, H., \& Dong, C. (2018). Trust and distrust in society and public perception of CSR: a crosscultural study. Social Responsibility Journal, 14(1), 1-19. doi:10.1108/SRJ-01-20170016

Ring, P. S., \& Van de Ven, A. H. (1992). Structuring cooperative relationships between organizations. Strategic Management Journal, 13(7), 483-498. doi:10.1002/smj.4250130702

Sako, M. (1992). Price, quality and trust: Inter-firm relations in Britain and Japan: Cambridge University Press.

Sako, M., \& Helper, S. (1998). Determinants of trust in supplier relations: Evidence from the automotive industry in Japan and the United States. Journal of Economic Behavior \& Organization, 34(3), 387-417. doi:10.1016/S0167-2681(97)00082-6

Sanchez, G., Trinchera, L., \& Russolillo, G. (2013). PLS-PM: tools for partial least squares path modeling (PLS-PM). R package version 0.4, 1 .

Sankowska, A. (2013). Relationships between organizational trust, knowledge transfer, knowledge creation, and firm's innovativeness. The Learning Organization, 20(1), 85100. doi:10.1108/09696471311288546

Seppänen, R., Blomqvist, K., \& Sundqvist, S. (2007). Measuring inter-organizational trust—a critical review of the empirical research in 1990-2003. Industrial Marketing Management, 36(2), 249-265. doi:10.1016/j.indmarman.2005.09.003

Shahmehr, F. S., Khaksar, S. M. S., Zaefarian, R., \& Talebi, K. (2015). How relational embeddedness affects business performance through trust: empirical research on emerging SMEs. International Journal of Entrepreneurship and Small Business, 26(1), 61-77. doi:10.1504/IJESB.2015.071320

Smith, K. G., Carroll, S. J., \& Ashford, S. J. (1995). Intra-and interorganizational cooperation: Toward a research agenda. Academy of Management Journal, 38(1), 7-23. doi: $10.5465 / 256726$

Sroka, W. (2011). Problem of trust in alliance networks. Organizacija, 44(4), 101-108. doi:10.2478/v10051-011-0010-0

Sroka, W., Cygler, J., \& Gajdzik, B. (2014). The transfer of knowledge in intra-organizational networks: A case study analysis. Organizacija, 47(1), 24-34. doi:10.2478/orga-20140003

Suseno, Y., \& Ratten, V. (2007). A theoretical framework of alliance performance: The role of trust, social capital and knowledge development. Journal of Management \& Organization, 13(1), 4-23. doi:10.1017/S1833367200003874

Tenenhaus, M., Vinzi, V. E., Chatelin, Y.-M., \& Lauro, C. (2005). PLS path modeling. Computational Statistics \& Data Analysis, 48(1), 159-205. doi:10.1016/j.csda.2004.03.005

Todorović, S., Radišić, M., Takači, A., Borocki, J., \& Kliestikova, J. (2019). Impact of internal additional compensations policy on revenues in cross-sectoral SME environment. European Journal of International Management, 13(6), 843-863. doi:10.1504/EJIM.2019.102838

Tsai, W., \& Ghoshal, S. (1998). Social capital and value creation: The role of intrafirm networks. Academy of Management Journal, 41(4), 464-476. doi:10.5465/257085

Uzzi, B. (1996). The sources and consequences of embeddedness for the economic performance of organizations: The network effect. American sociological review, 674-698. doi: $10.2307 / 2096399$

Vaccaro, A., Parente, R., \& Veloso, F. M. (2010). Knowledge management tools, interorganizational relationships, innovation and firm performance. Technological Forecasting and Social Change, 77(7), 1076-1089. doi:10.1016/j.techfore.2010.02.006 
Vanhala, M., \& Dietz, G. (2015). HRM, trust in employer and organizational performance. Knowledge and Process Management, 22(4), 270-287. doi:10.1002/kpm.1491

Vaníčková, R., \& Szczepańska-Woszczyna, K. (2020). The importance of organizational culture for innovation in the company. Polish Journal of Management Studies, 21(2), 425-445. doi:10.17512/pjms.2020.21.2.30

Vasa, L., Baranyai, Z., Kovacs, Z., \& Szabo, G. G. (2014). Drivers of trust: some experiences from Hungarian agricultural cooperatives. Journal of International Food \& Agribusiness Marketing, 26(4), 286-297. doi:10.1080/08974438.2013.833567

Wang, L., Yeung, J. H. Y., \& Zhang, M. (2011). The impact of trust and contract on innovation performance: The moderating role of environmental uncertainty. International Journal of Production Economics, 134(1), 114-122. doi:10.1016/j.ijpe.2011.06.006

Wei, H.-L., Wong, C. W., \& Lai, K.-h. (2012). Linking inter-organizational trust with logistics information integration and partner cooperation under environmental uncertainty. International Journal of Production Economics, 139(2), 642-653. doi:10.1016/j.ijpe.2012.05.036

Williamson, O. E. (1988). Corporate finance and corporate governance. The Journal of Finance, 43(3), 567-591.

Williamson, O. E. (1993a). Calculativeness, trust, and economic organization. The Journal of Law and Economics, 36(1, Part 2), 453-486. doi:10.1086/467284

Williamson, O. E. (1993b). Transaction cost economics and organization theory. Industrial and Corporate Change, 2(2), 107-156. doi:10.1093/icc/2.2.107

Wiroto, D. W., \& Taan, H. (2019). Business Continuity, Motivation, and Social Conditions of Young Entrepreneurs. Economics \& Sociology, 12(4), 166-332. doi:10.14254/2071789X.2019/12-4/10

Zaheer, A., McEvily, B., \& Perrone, V. (1998). Does trust matter? Exploring the effects of interorganizational and interpersonal trust on performance. Organization Science, 9(2), 141-159. doi:10.1287/orsc.9.2.141

Zaheer, A., \& Venkatraman, N. (1995). Relational governance as an interorganizational strategy: An empirical test of the role of trust in economic exchange. Strategic Management Journal, 16(5), 373-392. doi:10.1002/smj.4250160504

Zvaríková, K., \& Majerová, J. (2014). Financial literacy in the Slovak Republic. ProcediaSocial and Behavioral Sciences, 10, 1106-1115. doi:10.1016/j.sbspro.2013.12.957. 


\section{Appendix}

Table AI.1 Factor Loading Correlation

\begin{tabular}{|c|c|c|c|c|c|}
\hline & IT & IPT & IOT & IN & FP \\
\hline IT1 & 0.926 & & & & \\
\hline IT2 & 0.917 & & & & \\
\hline IT5 & 0.882 & & & & \\
\hline IPT1 & & 0.805 & & & \\
\hline IPT2 & & 0.805 & & & \\
\hline IOT1 & & & 0.650 & & \\
\hline IOT2 & & & 0.744 & & \\
\hline IOT3 & & & 0.807 & & \\
\hline IOT4 & & & 0.683 & & \\
\hline IN1 & & & & 0.862 & \\
\hline IN2 & & & & 0.659 & \\
\hline IN4 & & & & 0.876 & \\
\hline IN5 & & & & 0.847 & \\
\hline FP1 & & & & & 0.879 \\
\hline FP2 & & & & & 0.973 \\
\hline FP4 & & & & & 0.953 \\
\hline AVE & 0.148 & 0.640 & 0.500 & 0.662 & 0.760 \\
\hline
\end{tabular}

Source: Authors' own data. $n=103$

Table AI.2 Discriminant validity (Squared correlations < AVE)

\begin{tabular}{cccccc}
\hline & IT & IPT & IOT & IN & FP \\
\hline IT & 1 & 0.0275 & 0.1104 & 0.0142 & 0.0002 \\
\hline IPT & 0.0275 & 1 & 0.0560 & 0.0025 & 0.0000 \\
\hline IOT & 0.1104 & 0.0560 & 1 & 0.0005 & 0.0353 \\
\hline IN & 0.0142 & 0.0025 & 0.0005 & 1 & 0.0370 \\
\hline FP & 0.0002 & 0.0000 & 0.0353 & 0.0370 & 1 \\
\hline Mean Communalities (AVE) & 0.1481 & 0.640 & 0.500 & 0.662 & 0.760 \\
\hline
\end{tabular}

Source: own data. $n=103$

Table AI.3 Weights Dimension

\begin{tabular}{cccccc}
\hline \multirow{2}{*}{$\begin{array}{c}\text { Latent } \\
\text { variable }\end{array}$} & $\begin{array}{c}\text { Manifest } \\
\text { variables }\end{array}$ & Standard error & $\begin{array}{c}\text { Critical ratio } \\
(\mathrm{CR})\end{array}$ & $\begin{array}{c}\text { Lower bound } \\
(90 \%)\end{array}$ & $\begin{array}{c}\text { Upper bound } \\
(90 \%)\end{array}$ \\
\hline \multirow{3}{*}{ IT } & IT1 & 0.8450 & -1.4082 & -1.6051 & 1.0555 \\
\cline { 2 - 6 } & IT2 & 0.5041 & -0.6059 & -1.0364 & 0.6939 \\
\cline { 2 - 6 } & IT5 & 1.0375 & 1.2367 & -1.3784 & 1.5603 \\
\hline \multirow{2}{*}{ IPT } & IPT1 & 0.4416 & 1.7406 & -0.4647 & 1.0354 \\
\cline { 2 - 6 } & IPT2 & 0.4933 & 0.9166 & -0.5846 & 1.0373 \\
\hline \multirow{3}{*}{ IOT } & IOT1 & 0.1693 & 1.6337 & -0.0058 & 0.5307 \\
\cline { 2 - 6 } & IOT2 & 0.1764 & 2.9894 & 0.1985 & 0.7444 \\
\cline { 2 - 6 } & IOT3 & 0.0906 & 4.7592 & 0.2508 & 0.5675 \\
\hline \multirow{3}{*}{ IN } & IOT4 & 0.1957 & 0.3296 & -0.2772 & 0.3747 \\
\cline { 2 - 6 } & IN1 & 0.1622 & 1.5086 & -0.0872 & 0.4745 \\
\cline { 2 - 6 } & IN2 & 0.3218 & 0.6386 & -0.2152 & 0.9311 \\
\cline { 2 - 6 } & IN4 & 0.2004 & 1.9260 & -0.1378 & 0.6175 \\
\hline \multirow{3}{*}{ FP } & IN5 & 0.2417 & 1.5254 & -0.1822 & 0.5286 \\
\cline { 2 - 6 } & FP1 & 0.8614 & -0.1082 & -1.0938 & 1.6428 \\
\cline { 2 - 6 } & FP2 & 1.3457 & -0.0902 & -2.0778 & 2.6717 \\
\hline
\end{tabular}

Source: Authors' own data. $n=103$ 